\title{
Department of General Geology and Geotourism
}

\author{
Marek Doktor, Wojciech Mayer
}

\section{INTRODUCTION}

The recent Department (Chair) of General Geology and Geotourism has emerged at the very early stage of the history of the Academy of Mining (the initial name of our University) when the Department of Geology and Paleontology was established in 1920 at the Faculty of Mining - the only faculty of the Academy at that time. Professor Walery Goetel has been nominated for the Head of the Department. In 1926, the department was divided into the two independent units: Chair of Geology and Chair of Paleontology, the former still under the management of Professor Goetel. Within the Chair of Geology the Department of General Geology has been placed, also led by Prof. Goetel.

In next decades, both the Chair of Geology and the Department of General Geology have survived several, consecutive, major restructuring and minor organizational changes. After the World War II, the Faculty of Geology and Surveying was established, followed by the Faculty of Geology and, finally, by the Faculty of Geology and Exploration. In 1961, the Head of the Chair and the Department has become Professor Henryk Świdzinski.

In 1969, all Polish universities have been subjected to politically-induced, major restructuring - the traditional chairs were replaced by institutes. Hence, the Department of General Geology has been transformed into the Department of Dynamic Geology and anchored at the Institute of Regional Geology and Coal Deposits. Simultaneously, Docent Janusz Kotlarczyk has been nominated for the director of the new institute.

In 1974, the next restructuring resulted in the establishing of the Institute of Geology and Mineral Deposits. Within this new unit, the Department of Dynamic Geology was transformed into the Department of General and Mathematical
Geology, still under the supervision of Docent Janusz Kotlarczyk. After his retirement in 1999, Professor Tadeusz Słomka has become the new Head of the Department.

The major restructuring of our Faculty implemented in 2006 has dissolved the existing departments and established the new units. Among others, the new Department of Basic Geology and Environment Protection was organized. It was based on the staff of the former Department of General and Mathematical Geology, and the Department of Environment Protection (in operation since 1993) supported by some scientists of the past Department of Stratigraphy and Regional Geology, and by single researchers from other dissolved departments. Professor Tadeusz Słomka was nominated for the head of the new unit.

In 2007, our University has returned to its traditional structure - the basic organizational units have become the chairs. Hence, the Department of Basic Geology and Environment Protection evolved into the Chair of General Geology, Environment Protection and Geotourism, still managed by Prof. T. Słomka.

In 2011, the chair has been divided into the two independent units. One of them is the currently existing Chair of General Geology and Geotourism, under the supervision of, first, Prof. Słomka and then Prof. Marek Doktor.

\section{STAFF}

During the 96-years-long history of the Department/Chair of General Geology (in its successive embodiments), our staff has included an extended group of scientists, some of them beeing the leading persons in Polish Earth sciences. The heads of the department were: Prof. Waler Goetel followed by Prof. Henryk Świdziński and then 
by Prof. Janusz Kotlarczyk. In various time spans, the members of our staff were the future distinguished professors: Edward Passendorfer, Czesław Kuźniar, Stanisław Stopa, Stanisław Liszka, Stefan Kozłowski, Andrzej Róźkowski, Stefan W. Alexandrowicz, Antoni Kleczkowski and Aleksandra Kostecka, as well as many assistant professors and assistants appreciated in the Polish geological community.

The recent staff reflects a wide range of subjects and fields of interest together with a great variety of lectures and tutorials held by our members, far exceeding the initial, traditional general geology.

The staff of our Chair includes (in alphabetic order):

- full professors: Witold P. Alexandrowicz, Jan Golonka, Marek Krąpiec, Pavol Rybar ("visiting professor”, TU Kosice) and Tadeusz Słomka,

- associate professors: Marta Bąk and Marek Doktor,

- doctors: Henryk Duda, Elżbieta Szychowska-Krąpiec and Anna Waśkowska,

- assistant professors: Joanna Barniak, Tomasz Bartuś, Sławomir Bębenek, Diana Dryglas, Elżbieta Gałka, Michał Krobicki, Marek Łodziński, Wojciech Mastej, Wojciech Mayer, Krzysztof Miśkiewicz, Monika Pilarz, Paweł Różycki, Renata Stadnik, Piotr Strzeboński and Ewa Welz,

- assistants: Katarzyna Bębenek, Maria Czuj-Górniak and Andrzej Joniec.

- emeritus full professors: Janusz Kotlarczyk and Jacek Rajchel.

The fields of interest of our staff members are briefly described in the chapter "Scientific activity".

Below, concise biographical notes are presented of successive heads of our Department/Chair.

\section{Professor Walery Goetel (1889-1972)}

Born in 1889 in Sucha Beskidzka (in that Galicia and Lodomeria Province of the Austro-Hungarian Empire), he studied geology and paleontology at the Jagiellonian University in Kraków (19071910) and at the University of Vienna (1910-1912), from which he was granted the doctor degree in 1913. In 1918 he was granted the post-doctoral degree from the Jagiellonian University in Kraków. In 1920, Waler Goetel has been awarded the professorship of geology and paleontology at the
Academy of Mining, and has been nominated for the Head of just established Department of General Geology and Paleontology, followed by the Chair of General Geology, both at the Faculty of Mining of the Academy of Mining in Kraków. He had managed the chair until the retirement in 1960. In the years 1929-30 Prof. Goetel held the duties of Deputy Dean, and then, in the years 1930-1935, the Dean of the Faculty of Mining. In the years 1939-51, prof. Goetel had been the Rector of the Academy of Mining (since 1949 - Academy of Mining and Metallurgy). In 1952, he has become the corresponding member and, since 1960, the full member of the Polish Academy of Sciences. He was also the doctor honoris causa of the Mining Academy in Ostrava (then Czechoslovakia), of the University of Technology in Kraków and of our Academy of Mining and Metallurgy.

Professor Walery Goetel was a leading specialist in geology, stratigraphy, paleontology, geology of mineral deposits and protection of the nature. He was a distinguished expert in geology of the Tatra Mts. He invented and implemented the new, interdisciplinary branch of the Earth sciences, which he named "sozology" - the union of ecological, geological and geographical knowledge with the protection and rational utilization of natural resources (including the mineral raw materials). As a Rector of the Academy of Mining and Metallurgy, Prof. Goetel has planned, prepared and implemented the new model of the Academy, which covered the full range of utilization the mineral resources: from geological prospection and exploration through mining operations and mineral processing up to metallurgy and other utilization technologies, supported by supplementary sciences. Since 1963, Prof. Goetel has run the seminars at the Chair of Geology under the general name "Problems of protection of natural resources and security of sustained utilization of mineral resources".

\section{Professor Henryk Świdziński (1904-1969)}

Born in 1904 in Strzyżów Lubelski (Poland), he was graduated from the Faculty of Philosophy (nature section) at the University of Warsaw, where he studied geology and geography. From this university, he was granted the Philosophy Doctor in geology, in 1929, and the post-doctoral degree 
in 1937. He has started his scientific career at the University of Warsaw and at the State Geological Institute in Warsaw. In 1948, Prof. Świdziński has started the lectures on geological mapping at the Faculty of Geology and Land Surveying of the Academy of Mining in Kraków. In 1949, he has been nominated for professorship at that faculty and for the Head of the Department of Geological Mapping. In 1951, he was nominated for the Deputy Dean of the Faculty of Geology and Land Surveying. He was one of the "Funding Fathers" of the Faculty of Geology and Exploration, and was the first Dean of the Faculty in the years 19511952. In the years 1960-69, he held the function of the Head of the Chair of Geology.

Professor Henryk Świdziński was a distinguished specialist in stratigraphy, tectonics, geological mapping, regional geology of, particularly, the Holy-Cross Mts. and the Carpathians, in geology of minerals deposits, in geology of health resorts, in balneology and in nature protection. For instance, as a result of his long-lasting field studies, he published the geological map of the Eastern Polish Carpathians and the cross-sections through the Polish Flysch Carpathians.

\section{Professor Janusz Kotlarczyk}

Born in 1931 in Wadowice (Poland), he was graduated from the Faculty of Geology and Exploration in 1955 . He has started the research career at our faculty even before graduation. He was granted doctor of technical sciences degree in 1963 and post-doctoral degree in 1977. The next steps of his career were: docent in 1969, professor in 1980 and full professor in 1991. Since 1991, Professor Kotlarczyk has been nominated for the corresponding member of the Polish Academy of Sciences and since 1993 - also the corresponding member of the Polish Academy of Arts and Sciences. In the years 1969-1974, he had been the Head of the Institute of Regional Geology and Coal Deposits as well as the Head of the Department of Dynamic Geology, and in the years 1974-1999 he has held the function of the Head of the Department of General and Mathematical Geology, all at the Faculty of Geology and Exploration of the Academy of Mining and Metallurgy in Kraków.

Professor Janusz Kotlarczyk is a renowned specialist in sedimentology, stratigraphy and geology of the Carpathians as well as in computer geosciences and application of mathematical methods in geology. Among his leading achievement is the discovery and exploration of diatomites deposits in the Flysch Carpathians. Other appreciated publications are: the monograph of Carpathian ochres and the monograph of fish fauna from the Menilite Series. He is also the "Founding Father" of the school of mathematical geology at our faculty.

\section{Professor Tadeusz Słomka}

Born in 1948 in Świątniki Górne, ha was graduated from the Faculty of Geology and Exploration of the Academy of Mining and Metallurgy in Kraków, in 1972. His scientific career was dedicated to that faculty. He has been granted doctor of technical sciences degree in 1984 and post-doctoral degree in $\mathrm{n}$ 1996. He has become associated professor in 1999 and full professor of Earth sciences in 2008. In the years 1999-2011, Prof. Słomka had been the Head of the Chair of General and Mathematical Geology then transformed into the Chair of General Geology, Environment Protection and Geotourism. He was elected the Deputy Dean of the Faculty of Geology, Geophysics and Environment Protection at the University of Science and Technology (modern name of the Academy of Mining and Metallurgy) for the years 1996-1999, and the Dean of the Faculty for the years 1999-2005. In 2005, and again in 2008, he was elected the Deputy Rector for general affairs of the University of Science and Technology. In 2012, he was elected the Rector of our University. In 2016 he was elected again for the second term of the rectorship.

Prof. T. Słomka is a doctor honoris causa of the Shibaura Institute of Technology (Japan) and the Carpathian National University in Ivanofrankivsk (Ukraine).

Professor Tadeusz Słomka is a distinguished specialist in sedimentology of clastic sediments, mathematical modeling of geological processes and mineral deposits, and methodology of documentation and valorization of geotourism objects. He published a number of papers on sedimentology of the Carpathian flysch formations, on the mechanisms of flysch sedimentation and on paleogeography of sedimentary basins. He is the initiator and organizer of geotourism - a new, 
interdisciplinary branch of applied Earth sciences and educational specialization. He is also the initiator and first Chief Editor of the "Geotourism-Geoturystyka” quarterly (until 2013).

\section{Professor Marek Doktor}

Born in 1949 in Bielsko-Biała (Poland), he was graduated in 1972 from the Faculty of Geology and Exploration of the Academy of Mining and Metallurgy in Kraków. After graduation he has started scientific career at the Institute of Geological Sciences of the Polish Academy of Sciences in Kraków. He was granted the doctor of Earth sciences degree in 1980. Since 2004 he has been lecturing at the Faculty of Geology, Geophysics and Environment Protection and in 2006 he has moved to permanent scientific post at this faculty. In 2009, he was granted the post-doctoral degree and in 2012, he has become associated professor at our faculty. Since 2011, he has been nominated the Head of the Chair of General Geology and Geotourism.

Professor Marek Doktor is a specialist in sedimentology of fossil and recent clastic sediments, particularly the coal-bearing formations of the Upper Silesian Coal Basin, in geology of the Antarctic areas and in application of mathematical methods in geology. His leading scientific achievements are: the recognition of sedimentary environments of Upper Caboniferous Mudstone Series and Cracow Sandstone Series as well as the studies on the system of anastomosing Narew River. He was a member of three Polish polar expeditions to the Western Antarctic. He is currently the co-organizer of education and research in geotourism the new, interdisciplinary branch and educational specialization run at the Faculty of Geology, Geophysics and Environment Protection. Since 2013, he is the Chief Editor of the "Geotourism/Geoturystyka" quarterly.

\section{EDUCATION}

Since the very beginning of the history of our Department/Chair, the educational activity of our staff has been focused on the introduction of first-year, full-time and part-time students into the principles of geology. Hence, the educational offer of the Chair includes lectures, tutorial and field trainings in general geology and its clones: dynamic geology, basic geology, introduction to geology, Earth sciences, principles of geology and geology-mineralogy-petrograhy. The specific curricula were directed to students of various courses at our faculty but also to students of other faculties of the early Academy of Mining, then the Academy of Mining and Metallurgy, and, finally, the recent AGH University of Science and Technology. Hence, our staff members lectures at the Faculty of Mining and Geoengineering (formerly: Faculty of Mining), at the Faculty of Mining Surveying and Environmental Engineering, and at the Faculty of Drilling, Oil and Gas (fomerly: Faculty of Petroleum Drilling). Important elements of this education are various field training sessions for the first-year students run in the four different geological regions of Poland: the Silesian-Kraków Monocline, the Pieniny Klippen Belt and the Flysch Carpathians, the Sudety Mts. and the Baltic Sea coast.

Moreover, our staff runs several specialized lectures and tutorials for students of second and third years of the I level as well as for master degree (II level) students, e.g.: sedimentology, applied sedimentology, marine geology, geotectonic principles of mineral exploration, statistics, mathematical methods in geology (also for students of the Jagiellonian University), mathematical methods in mineral exploration and geoenvironmental modelling. Additionally, our staff has proposed several optional lectures for students of all levels and courses, as e.g.: glaciology, planetary geology, archeoastronomy, graduates of geology as businessmen, numerical modeling in geology, representative geological sampling, Visual $\mathrm{Ba}$ sic programming, image identification and neural networks in Earth sciences, etc. Also, optional lectures were provided for students of the Faculty of Management (e.g., national parks in the USA) and for the Faculty of Human Sciences (technical culture and its resources).

In 1998, the basic change of educational programs was implemented at out Faculty. Among the new proposals, the first curriculum was presented of geotourism - a new course combining the then standards for Geology and Mining, and Tourism and Recreation courses. In 1999, the Geotourism was initiated as specialization at the Geology and 
Mining course. It was the first such specialization opened at the universities in Poland. Almost immediately it has gained significant popularity at out Faculty. In 2009, the Senate of our University has granted the rights to open the Tourism and Recreation course to our Faculty, initially at the I level (BSc degree) and then at the II level (MSc degree), the latter having three specializations: Geotourism, Health Resort Tourism and Ecotourism. That was the first such course opened at the Polish technical university.

Education in geotourism was an innovative concept based upon a standard education of applied geologists supplemented by adequate specialized knowledge from the field of tourism industry. It was the response of our Faculty to still more and more limited job opportunities for geologists in Poland and abroad, and, from the other side, to quickly growing, domestic and international tourism industry (including the specialized tourism) as well as to the newly emerging concepts of geoconservation, protection of geodiversity and protection of the Earth heritage (e.g., geoparks). Simultaneously, new specialists have been employed at our Chair. Also, the educational offer of the Chair was much extended by implementation of new topics, e.g.: geography of tourism in Poland and in the world, principles of tourism, tourist flow services, preparation of tourism product, management of tourism values or marketing in tourism combined with a number of geological topics, e.g.: general and tourism geology, geotourism, landscapes of the Earth, marine coasts and geoparks. The crucial elements of this educational concept are field training sessions: tourism attractions in Poland (for BSc course) and tourism attractions in Europe (for Master degree course)

Our staff members run also lectures and tutorials for PhD students (III level studies).

In last decades, the staff of our Chair organized the seminar "Application of mathematical methods and computer science in geology".

\section{RESEARCH}

For decades, the staff of our Department/Chair has run the extended studies on geology of the Polish Carpathians focused particularly on sedimentology and stratigraphy of the Silesian and the Skole units, and the Pieniny Klippen Belt, on stratigraphy, sedimentology and paleogeography of the northern Flysch Carpathians including the role of intra-basinal ridges as well as the recognition of deep structures in the Carpathian orogen using the magnetotelluric soundings combined with geological interpretation of the results.

An important investigation of the Carpathian diatomites led to the discovery and exploration of several deposits of this valuable mineral raw material.

Recently, our staff members continue micropaleontological, biostratigraphic, microfacial and geochemical analyses of Cretaceous sediments from the Magura and the Silesian units of the Outer Carpathians, from the Umbria-Marche Basin in the Apenines and from the Cambrian shales from the Pepper Mts. in Poland.

A working group runs the biostratigraphic, paleoecological and taxonomic investigations of the Tethyan sediments. The results will contribute to the recognition of geological history of the Alpine orogen.

The micropaleontological studies on the Hieroglyphic Beds in the Polish Carpathians led to the discovery of a new species of agglutinating foraminifer - Bulbobaculites gorlicensis n.sp.

Our staff member was the co-editor of the monograph: "The Carpathians and Their Foreland: Geology and Hydrocarbon Resources". This is the first book written by Polish co-author, which was issued by the American Association of Petroleum Geologists. The monograph is a significant achievement providing geological, geophysical and petroleum exploration data, which are crucial for educational, cognitive and practical purposes concerning the hydrocarbon exploration in the Carpathians and in their foreland. It is also important for intensification of oil and gas production from the existing deposits.

Our staff members continue sedimentological research of carbonate formations in the Pieniny Klippen Belt, the Upper Carboniferous sediments from the Upper Silesian Coal Basin, and Tertiary lignite formation from the Bełchatów and Turów deposits.

The research project concerning the metal deposits and occurrences in the Karkonosze-Izera Block of the Sudety Mts. resulted in several 
papers published in leading domestic periodicals. The summary of the project was published in a world-renowned geological journal. Moreover, an analysis was completed of geoctectonic evolution of the Sudety Mts. and adjacent area in the Phanerozoic. A working group from our Chair participated in the inventory of landslides in Poland (outside the Carpathians) and in preparation of relevant database.

Recently, our staff members participate in the studies on global paleogeography, plate tectonics and distribution of paleoenvironments and paleolithofacies. The results comprise the maps illustrating geodynamic evolution of the Earth from the Cambrian to the Neogene, the breakups of supercontinents, the rifting and sea-floor spreading episodes, the growth and the collisional closure of the oceans, and the coalescence of continents leading to the formation of new supercontinents. The resulting publications are the first such comprehensive data sources in world literature.

The Blue Gas project includes the GASGEOLMOD module run by our staff members. The project embraces the analysis of regional geology, stratigraphy and tectonics of the East-european Platform applied to the exploration of unconventional energy sources.

Since decades, our staff members have participated in studies on methodology and application of mathematical methods in geology, particularly in mathematical modeling of deposition processes of flysch and coal-bearing formations, in the methodological improvements of quantitative stratigraphy, in the investigations of variability of various mineral deposits, and in the creation of data storage and processing systems applied to the Carpathian flysch, hard coal and lignite deposits. They also participated in preparation of software suitable for studies on cyclicity of sediments applied to lithofacial variability of Neogene sediments in the Bełchatów lignite deposit including the innovative methodology based upon the Markov chains. Other software applications were built for exploration and assessment of $\mathrm{Zn}-\mathrm{Pb}$ ores, and for dendrochronological analyses. In the last years, our staff members have studied the topoclimatic variability of the Ojców National Park area using the GIS data and modern, specialized software (ArcGIS and Model Builder).
The working group originating from the past Department of Stratigraphy and Regional Geology has been active in the studies on geochronology and changes in depositional environments of the Holocene and the Pleistocene based upon dendrochronological and malacological analyses, and radiocarbon datings. Dendrochronological analyses include the reconstruction of standards suitable for Holocene subfossil oak wood and for conifer trees from the last millenia. This methodology is useful for many interdisciplinary research projects, e.g., datings of alluvia, archeological objects, art and architectural monuments. Moreover, dendrochronology is helpful in evaluation of environment degradation in endangered areas, in reconstruction of hydrological changes in peat-bogs and in identification of periods of landslide activity in the Carpathians during last centuries. The malacological studies based upon fossiled bivalves from Quaternary sediments are focused on analysis of environmental features and their evolution during the accumulation of sediments. The results enable us to reconstruct quite accurately the conditions prevailing around the depositional centers. Moreover, malacological methods are applied in evaluation of human impact on natural environment.

An important field of interest of our staff is the nature protection, e.g., documentation and preparation of applications for legal protection of the "Stone Forest in the Roztocze" geopark.

In last years, the working group from our Chair and cooperating staff members of the Lower Silesian Branch of the State Geological Institute has completed the project of "The Sudetic Geostra$\mathrm{da}$ ". This is the geotourism trail designed for motorized tourists and bikers, which leads through less known and less popular regions of the Sudety Mts. and the Sudetic Foreland. The same working group run the two consecutive, applied projects of geosites catalogues. The first included a number of selected geosites in Poland and the second dealt with the geosites located within the areas of existing nature reserves and nature monuments in Poland.

Recently, the working group from our Chair participates in preparation of two applications for new geoparks: the Transnational Pieniny Geopark (in cooperation with the partners from the Technical University in Kosice, Slovakia) and 
the Moravian-Silesian Beskid Geopark (in cooperation with Czech partners). Moreover, the preliminary studies have been initiated of the next, Polish-Slovakian Transnational Geopark of the Flysch Carpathians. The feasibility study was undertaken for geoarcheological trail in the area of the Opatów Highland.

The field observations run in various parts of Poland combined with the collection of mineral, rock and fossil samples together with photographic documentation lead to the preparation of a monograph directed to collectioners.

The studies have been continued on health resorts and health-resort communes. These are focused on development of specific tourism products, measurements of tourism functions and development of relevant strategies for the change management in health-resort communes.

The comprehensive model of valorization of geotourism objects is currently under preparation.

The results of scientific and applied activity of our staff are contained in over 800 papers, published partly in renowned world periodicals (e.g.,
Geological Magazine, Journal of Micropaleontology, Geological Quarterly, Ore Geology Reviews). Selected results were presented during the international conferences, including the International Geological Congress, the International Association of Sedimentologists Meeting, the Central European Tectonic Studies Group Meeting, the Geological Congress of the Carpatho-Balkan Geological Association, the Czech-Slovak-Polish Paleontological Conference and the Geological Evolution of the Western Carpathians Conference as well as during the domestic conferences (Ist and IInd Polish Geological Congress, GEOTOUR, JURASSICA conference and GeoShale conference).

Up to now, our chair has graduated: 167 fulltime MSc students, 84 part-time MSc students of various courses, 171 part-time BSc and engineer students, 159 students of the I level (mostly BSc and engineer at Environment Protection course), 305 students of the I level (BSc) of Tourism and Recreation course, 70 students of the II level (MSc) of Tourism and Recreation course, and 15 students of III level ( $\mathrm{PhD}$ course in natural sciences). 